\title{
Analiza rizika u zamjenskom cjeloživotnom modelu ulaganja u drugom stupu mirovinskog osiguranja u Hrvatskoj
}

Kovačević, Renata; Latković, Mladen

Source / Izvornik: Odabrani prijevodi, 2015, 6, 1 - 20

Journal article, Published version

Rad u časopisu, Objavljena verzija rada (izdavačev PDF)

https://doi.org/10.3326/op.27

Permanent link / Trajna poveznica: https://urn.nsk.hr/urn:nbn:hr:242:384290

Rights / Prava: Attribution-NonCommercial-NoDerivatives 4.0 International/ImenovanjeNekomercijalno-Bez prerada 4.0 međunarodna

Download date / Datum preuzimanja: 2023-04-26

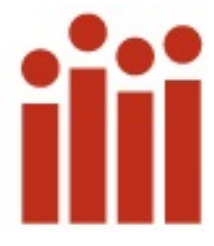

Repository / Repozitorij:

Institute of Public Finance Repository

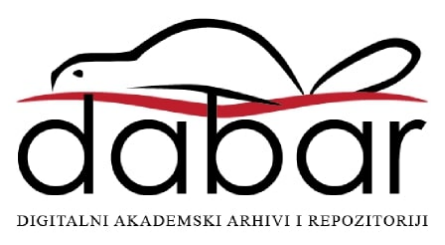


Institut za

javne financije

Smičiklasova 2I | Zagreb

www.ijf.hr | ured@ijf.hr

T: oI/4886-444 | F: OI/48I9-365

\title{
ANALIZA RIZIKA U ZAMJENSKOM GJELOŽIVOTNOM MODELU ULAGANJA U DRUGOM STUPU MIROVINSKOG OSIGURANJA U HRVATSKOJ
}

\author{
UNIV. SPEC. ACT. SC. RENATA KOVAČEVIĆ" \\ ČLANAK ${ }^{* *}$ \\ MR. SC. MLADEN LATKOVIĆ* \\ JEL: GII, GI8,Gi9, G23 \\ DOI: $10.3326 /$ op. 27
}

\section{OdABRANI \\ PRIJEVODI}

ISSN $1847-7445$

BR. 27/I5

citirati: Kovačević, R. i Latković, M. 20I5. Risk analysis of the proxy lifecycle investments in the second pillar pension scheme in Croatia. Financial Theory and Practice, 39 (I), str. 3I-55. http://www.fintp.hr/upload/files/ft $\mathrm{p} / 2015 / \mathrm{I} /$ kovacevic_latkovic.pdf

Autori zahvaljuju trima anonimnim recenzentima na korisnim sugestijama koje su pridonijele poboljšanju članka. Stavovi izneseni u ovome radu su osobni stavovi autora i ne predstavljaju nužno stavove tvrtke u kojoj su zaposleni.

Primljeno: I. lipnja 20I4.

Prihvaćeno: 4. studenog 2014.

Rad je prijavljen za godišnju nagradu “Zaklade prof. dr. Marijan Hanžeković” za 2OI4. godinu.

Renata KOVAČEVIĆ

Raiffeisen društvo za upravljanje obveznim i dobrovoljnim mirovinskim fondovima d.d., Heinzelova 44, Ioooo Zagreb

e-mail: renata.kovacevic@rmf.hr

Mladen LATKOVIĆ

Raiffeisen društvo za upravljanje obveznim i dobrovoljnim mirovinskim fondovima d.d., Heinzelova 44, Ioooo Zagreb

e-mail: mladen.latkovic@rmf.hr 


\section{UVOD}

Dizajn mirovinskog modela koji se zasniva na individualnim ulaganjima, tj. modelu definiranih doprinosa, u obveznom sustavu mirovinskog osiguranja (II. stup) u zadnjih je nekoliko godina doživio značajne promjene kod mnogih država koje su ga uvele (Impavido et al., 20Io.). Osnova za takve promjene su akademska istraživanja koja su pokazala da cjeloživotni model ulaganja (life-cycle investments) imovine mirovinskih fondova, koji se zasniva na promjeni alokacije portfelja mirovinskog fonda s vremenom provedenim u akumulacijskoj fazi, ima određenu dobrobit za osiguranike (Bodie et al., 2008.; Viceira 2007.). Promjene koje su se dogodile u II. stupu zasnovane su na zamjenskom cjeloživotnom modelu ulaganja (proxy life-cycle) koji s protekom vremena ulaganja omogućava promjene $\mathrm{u}$ alokaciji portfelja putem prelaska osiguranika iz mirovinskog fonda veće očekivane rizičnosti u fond s manjom očekivanom rizičnosti.

Egzaktni, tj. dinamički cjeloživotni model omogućavao bi postepenu prilagodbu alokacije imovine osiguranika u vremenu, tj. kontinuiranu promjenu omjera ulaganja u dionice i obveznice, što u praksi nije oportuno izvedivo za kolektivne sheme ulaganja. Stoga se $\mathrm{u}$ praksi uvodi diskontinuirana promjena alokacije portfelja za osiguranike putem manjeg broja mirovinskih fondova različitih ciljanih alokacija iz kojih proizlaze različiti očekivani prinosi tih fondova kao i njihovi različiti očekivani profili rizičnosti.

Polazna ideja cjeloživotnog modela ulaganja je da osiguranici na početku ulaska u mirovinski sustav lakše mogu podnijeti rizična ulaganja dok je osiguranicima s duljim mirovinskom stažem sigurnost ulaganja važnija od visokih prinosa. U počecima mirovinske štednje osiguranici na osobnom računu u pravilu imaju znatno manje ušteđenih sredstava od osiguranika koji se nalaze neposredno pred umirovljenje, pa eventualni pad vrijednosti do tad ušteđenih sredstava ne utječe značajno na iznos očekivanih ukupno akumuliranih sredstava. Kod osiguranika s duljim mirovinskim stažem iznos dotad ušteđenih sredstava je velik, i u tom razdoblju svaki pad vrijednosti uzrokuje značajne gubitke u ukupnom iznosu očekivane kapitalizirane štednje. Stoga, unutar okvira cjeloživotnog modela ulaganja, imovinu osiguranika s kraćim mirovinskim stažem preporučuje se ulagati u financijske instrumente višeg očekivanog rizika, koji dugoročno donose visoke prinose (poput primjerice dionica), dok se imovinu osiguranika $s$ duljim stažem preporučuje ulagati u financijske instrumente nižeg očekivanog rizika (poput primjerice državnih obveznica).

Drugi stup mirovinskog osiguranja u Hrvatskoj započeo je s radom 2002. godine te je za sve osiguranike pretpostavljao jednak profil rizičnosti nekog obveznog mirovinskog fonda. Jedina fleksibilnost u alokaciji imovine bila je diskrecijska odluka upravitelja fondova da prilagode strukturu ulaganja tržišnim uvjetima. Obzirom da je minimalni udio domaćih državnih obveznica (do ulaska u Europsku uniju) morao biti 50\% neto imovine obveznog mirovinskog fonda, maksimalna mogućnost ulaganja u financijske instrumente veće rizičnosti (dionice i investicijske fondove koji ulažu u dionice) iznosila je 50\% neto imovine fonda (Zakon o obveznim i dobrovoljnim mirovinskim fondovima, 1999.). Međutim, u praksi se takvi nivoi ulaganja u dionice nisu nikada mogli ostvariti zbog ograničenja ulaganja od 20\% imovine fonda u inozemna tržišta te nedostatka ulaganja u domaće dioničko tržište. Povijesni nivoi ulaganja u domaće i inozemno dioničko tržište kretali su se oko razine od $25 \%$ imovine fondova s većim udjelom domaćih dionica spram inozemnih dionica (izvor: mjesečni izvještaji Hrvatske agencije za nadzor financijskih usluga - HANFA). 
Zamjenski cjeloživotni model ulaganja u II. stupu uveden je u Hrvatskoj 20I4. godine na način da su definirana tri obvezna mirovinska fonda različitih kategorija, tj. različitih strategija ulaganja: A, B i C (Zakon o obveznim mirovinskim fondovima, 20I4.). Fond kategorije A ima najveći profil rizika u kojem je maksimalni udio u dionicama 55\% imovine fonda (teorijski $65 \%$ ukoliko se svim alternativnim ulaganjima stvori izloženost prema dioničkom tržištu) te ga možemo okarakterizirati kao fond balansiranog profila rizičnosti. Fond kategorije B ima maksimalnu izloženost dionicama u iznosu od $35 \%$ imovine fonda te ga možemo smatrati fondom umjereno konzervativnog profila rizičnosti. U fondu kategorije $\mathrm{C}$ nije moguće stvoriti izloženost prema dioničkom tržištu te ga smatramo fondom konzervativnog profila rizičnosti.

Obzirom na pomalo začuđujući nedostatak istraživanja o rizičnostima koji proizlaze iz ulaganja mirovinskih fondova 2. stupa u zamjenskom cjeloživotnom modelu ulaganja spram njihovih strategija ulaganja (osim Scheuenstuhl et al., 20Io.), a koje u najvećem dijelu proizlaze iz zakonski definiranih ograničenja ulaganja, pristupili smo analizi očekivanih prinosa i rizika obveznih mirovinskih fondova različitih kategorija u Hrvatskoj. Cilj istraživanja je utvrditi efikasnost primijenjenog modela zamjenskog cjeloživotnog modela ulaganja $u$ odnosu na dosadašnji model 2. stupa u Hrvatskoj te izvesti određene zaključke koji bi mogli pomoći u poboljšanju istog ili pomoći u nekom budućem redizajnu 2. stupa kod drugih država koje su ga implementirale.

Članak je organiziran na sljedeći način: u drugom poglavlju opisat ćemo cjeloživotni model ulaganja i njegovu zamjensku verziju uz osvrt na njihovu primjenu u svijetu te specifičnosti vezane uz Hrvatsku. Treće poglavlje opisuje parametarski model za izračun akumulirane štednje koji je prilagođen zamjenskom cjeloživotnom modelu ulaganja te način izračuna utjecaja tržišnog šoka na iznos akumulirane štednje. U četvrtom poglavlju analizirat ćemo očekivane prinose i rizičnosti obveznih mirovinskih fondova kategorija A, B i C dok ćemo u petom poglavlju analizirati očekivana ukupno akumulirana sredstva u različitim scenarijima štednje te robusnost pojedinih scenarija na pojavu tržišnog šoka. U šestom poglavlju analizirat ćemo rizik koji proizlazi iz promjene fonda u nepovoljnom trenutku. Na kraju, zadnje poglavlje donosi analizu rezultata istraživanja.

\section{GJELOŽIVOTNI MODELI ULAGANJA}

Kod postavljanja strategije ulaganja mirovinskih fondova na dugi rok javlja se pitanje kako ostvariti primjeren prinos fonda, a istovremeno zaštititi osiguranike od rizika povezanih s ulaganjima na tržištu kapitala. Za slučaj jednokratne uplate u fond i vrlo dugog horizonta ulaganja moderna teorija portfelja nedvosmisleno ukazuje da je optimalna alokacija portfelja između različitih klasa imovine dana jednoznačno spram definirane averzije prema riziku investitora, da je određena skupom parametara kao što su očekivani prinosi, rizici i međusobne korelacije između pojedinih klasa imovine, bezrizična kamatna stopa te da je vremenski neovisna.

Međutim, vremenski horizont ulaganja osiguranika u mirovinskom fondu tipično se kreće u rasponu od 35 do 45 godina, a uplate, u prosjeku spororastućeg intenziteta, se uobičajeno događaju u jednakim vremenskim intervalima. Nadalje, averzija prema riziku očekivano raste kako se završava akumulacijska faza i počinje faza isplate mirovine. U takvim okolnostima moguće je da optimalna struktura ulaganja ima vremenski zavisnu dinamiku. Istraživanja pokazuju da bi optimalna strategija ulaganja mirovinskog fonda trebala biti opisana cjeloživotnim modelom koji omogućava postepenu prilagodbu alokacije portfelja mirovinskog fonda $\mathrm{u}$ vremenu, tj. kontinuiranu promjenu omjera 
ulaganja u dionice i obveznice (za pregled vidjeti, npr., Bagliano, et al., 20o9.; Potočnjak i Vukorepa, 20I2.).

Većina istraživanja cjeloživotnog modela ulaganja mirovinskih fondova (Castañeda et al., 20II.) pokazuju da na početku akumulacijske faze ulaganja imovine fonda pretežno treba biti alocirana $u$ dionice uz manji udio obveznica u portfelju (umjereno agresivna struktura ulaganja), dok se na kraju akumulacijske faze alokacija svodi na pretežita ulaganja u obveznice dok se značajno manji dio ulaže u dionice (umjereno konzervativna struktura ulaganja). Osnovna ideja je da osiguranici na početku ulaska u mirovinski sustav lakše mogu podnijeti rizičnija ulaganja jer, osim što imaju manja akumulirana sredstva, imaju i više vremena do umirovljenja te veću vjerojatnost da umanje $\mathrm{i}$ nadoknade eventualne gubitke. S druge strane, osiguranici s duljim mirovinskom stažem preferiraju sigurnost ulaganja spram zarade obzirom na veliki iznos akumuliranih sredstava i kraći rok za nadoknadu eventualnih gubitaka.

Osiguranici bi, stoga, trebali imati mogućnost promjene alokacije između dionica i obveznica u vremenu te se postavlja pitanje načina izvođenja takvih promjena, ali uz zadržavanje mehanizma kolektivne sheme ulaganja. Jedno od rješenja je cjeloživotno modeliranje ulaganja s kontinuiranim podešavanjem alokacije. Takav mehanizam moguće je postići definiranjem kohortnih grupa osiguranika s približno istim vremenom do umirovljenja. U praksi bi to značilo da svi osiguranici s rasponom od, npr. 5 godina u vremenu do umirovljenja ulažu u isti fond kojem se alokacija kroz čitavu akumulacijsku fazu podešava kontinuirano prema modelu cjeloživotnog ulaganja. Takav približno egzaktni model cjeloživotnog ulaganja u praksi znači i daleko veći broj mirovinskih fondova, a posljedično i povećane troškove njihovog upravljanja.

Rješenje problema provođenja cjeloživotnog ulaganja može se postići i definiranjem nekoliko mirovinskih fondova koji ulažu u imovne različitih klasa rizičnosti, a optimalna se alokacija za nekog osiguranika dobiva ulaganjem njegovih sredstava u određenom postotku u pojedine mirovinske fondove. Ovdje je očiti problem određivanje optimalne alokacije za pojedinog osiguranika koja može s upravitelja mirovinskog fonda biti delegirana ili na osiguranika ili na zakonodavca putem automatskog sustava alociranja. Također, troškovi administriranja ovakve sheme su povećani zbog dodatnog vođenja registra udjela po svakom od fondova i složenijeg mehanizma rasporeda doprinosa po fondovima.

Na kraju, cjeloživotno ulaganje se može aproksimativno postići i formiranjem nekoliko mirovinskih fondova različitih profila rizičnosti te automatskom promjenom članstva osiguranika iz fonda većeg profila rizika u fond manjeg profila rizika kako se bliži vrijeme njegova umirovljenja. Takav zamjenski cjeloživotni model ulaganja (proxy life-cycle) simulira optimalnu promjenu alokacije imovine fonda u akumulacijskoj fazi uvodeći nekoliko fondova s približno konstantnim profilima rizika za pojedine faze akumulacije te unaprijed definirana vremena obveznog prelaska $u$ fond manjeg profila rizika. Napomenimo da se približna konstantnost profila rizičnosti pojedinog fonda odnosi na mogućnost promjene alokacije upravitelja fonda u ovisnosti o tržišnim uvjetima. Također, moguće je dozvoliti osiguranicima da u određenom trenutku sami promjene kategoriju rizičnosti fonda ovisno o njihovim osobnim preferencijama prema riziku, a koje ne moraju biti uvjetovane tržišnim uvjetima.

U cilju optimizacije troškova sustava s jedne strane i nastojanjima da se cjeloživotni model ulaganja što bolje definira zamjenskim modelom, $\mathrm{u}$ praksi se definiraju tri do pet mirovinskih fondova različitih kategorija rizika. Ovisno o broju fondova potrebno je definirati i vremena automatskog 
prelaska $u$ fond nižeg profila rizičnosti, a ako se po osobnom izboru osiguranika omogući i prelazak u fond različitog profila rizičnosti, potrebno je definirati i uvjete pod kojima se takav prelazak može ostvariti. Napomenimo da u oba slučaja promjena fonda uvodi rizik prelaska u nepovoljnom trenutku, tj. u razdobljima kada zbog pada cijena na tržištu kapitala dolazi do pada vrijednosti dotad akumulirane štednje osiguranika, a koja se ne može nadoknaditi ukoliko osiguranik nakon pada prijeđe $u$ fond nižeg profila rizičnosti. U ovom članku ćemo se posebno osvrnuti na takve nepovoljne scenarije i analizirati njihov utjecaj na ukupno akumulirana sredstva.

Prema podacima Svjetske banke, zamjenski cjeloživotni model s mirovinskim fondovima različitih profila rizičnosti uvelo je desetak zemalja, među kojima su Čile, Estonija, Mađarska, Meksiko, Peru, Slovačka te Poljska (Castañeda et al., 20II.), dok se za uvođenje zamjenskog cjeloživotni model pripremaju i Bugarska i Kolumbija (Impavido et al., 20Io.). Većina zemalja odlučila se za sustav od tri različita fonda s konzervativnim, uravnoteženim i agresivnim profilima rizičnosti, a koji su u najvećoj mjeri definirani ograničenjima ulaganja u pojedine klase imovine i gdje osiguranik u svakom trenutku može biti samo u jednom fondu. Ipak, postoje izuzeci koji su uveli i po pet fondova različitih očekivanih rizika (poput Čilea i Meksika), te koji svojim osiguranicima pružaju veliku fleksibilnost prilikom odabira fondova.

Tako, primjerice, Čile omogućava osiguranicima da svoju imovinu rasporede $u$ dva fonda $u$ proizvoljnom omjeru, kako bi se umanjio rizik prelaska iz jednog u drugi fond te dozvoljava promjenu trenutačnog fonda $u$ fond nižeg ili višeg očekivanog rizika, uz izuzetak za osiguranike koji se nalaze neposredno pred umirovljenje kojima se ne dozvoljava prelazak u najrizičniji fond. Unatoč velikom izboru fondova, te fleksibilnosti i jednostavnosti odabira, u Čileu se oko 65\% osiguranika raspoređuje automatski, sukladno zakonskim ograničenjima članstva u pojedinom fondu (Impavido et al., 2OIO.).

U tablici I. dan je prikaz ograničenja na ulaganja u dionice po fondovima za navedene države koje su uvele zamjenski cjeloživotni model ulaganja mirovinskih fondova, dok su u tablici 2. dani kriteriji automatskog rasporeda osiguranika za te države.

\section{TABLIGA I.}

Ograničenja ulaganja u dionice za mirovinske fondove u državama sa zamjenskim cjeloživotnim modelom ulaganja (\% neto imovinske vrijednosti fonda)

\begin{tabular}{|c|c|c|c|c|c|}
\hline & Fond A & Fond B & Fond C & Fond D & Fond $\mathrm{E}$ \\
\hline Čile & 80 & 60 & 40 & 20 & 5 \\
\hline Meksiko & 30 & 25 & 20 & I5 & $\mathrm{O}$ \\
\hline Peru & 80 & 45 & IO & & \\
\hline Mađarska & $\langle 40$, IOO $\rangle$ & $\langle\mathrm{IO}, 4 \mathrm{O}\rangle$ & IO & & \\
\hline Slovačka & 80 & 50 & $\mathrm{O}$ & & \\
\hline Estonija & 75 & 25 & $\mathrm{O}$ & & \\
\hline Poljska & 75 & 35 & 7,5 & & \\
\hline
\end{tabular}

Izvor: Castañeda i Rudolph (20II.), osim za Poljsku alokacija benchmarka za fondove različitih rizičnosti (Wojcieh, 20II.) i Čile (Arthur, 20og.). 
TABLica 2.

Zakonska ograničenja trajanja članstva u pojedinom fondu obzirom na dob osiguranika

\begin{tabular}{|c|c|c|c|c|c|}
\hline & Fond A & Fond B & Fond C & Fond D & Fond E \\
\hline \multirow{2}{*}{ Čile } & & \multirow{2}{*}{$\begin{array}{l}\text { Muškarci i žene } \\
\text { do } 35 \text { godina }\end{array}$} & $\begin{array}{l}\text { Muškarci od } 35 \\
\text { do } 55 \text { godina }\end{array}$ & $\begin{array}{l}\text { Muškarci stariji } \\
\text { od } 55 \text { godina }\end{array}$ & \\
\hline & & & $\begin{array}{l}\text { Žene od } 35 \text { do } 50 \\
\text { godina }\end{array}$ & $\begin{array}{l}\text { Žene starije od } \\
50 \text { godina }\end{array}$ & \\
\hline Meksiko & $\begin{array}{l}\text { Muškarci i žene } \\
\text { do } 26 \text { godina }\end{array}$ & $\begin{array}{l}\text { Muškarci i žene } \\
\text { od } 26 \text { do } 37 \text { godina }\end{array}$ & $\begin{array}{l}\text { Muškarci i žene } \\
\text { od } 37 \text { do } 45 \text { godina }\end{array}$ & $\begin{array}{l}\text { Muškarci i žene } \\
\text { od } 45 \text { do } 55 \\
\text { godina }\end{array}$ & $\begin{array}{l}\text { Muškarci i žene } \\
\text { od } 55 \text { godina }\end{array}$ \\
\hline Peru & & $\begin{array}{l}\text { Muškarci i žene } \\
\text { do } 60 \text { godina }\end{array}$ & $\begin{array}{l}\text { Muškarci i žene } \\
\text { od } 6 \text { o godina }\end{array}$ & & \\
\hline Mađarska & $\begin{array}{l}\text { Muškarci i žene } \\
\text { do } 47 \text { godina }\end{array}$ & $\begin{array}{l}\text { Muškarci i žene } \\
\text { od } 47 \text { do } 57 \text { godina }\end{array}$ & $\begin{array}{l}\text { Muškarci i žene } \\
\text { od } 57 \text { godina }\end{array}$ & & \\
\hline Slovačka & $\begin{array}{l}\text { Muškarci i žene } \\
\text { do } 47 \text { godina }\end{array}$ & $\begin{array}{l}\text { Muškarci i žene } \\
\text { do } 55 \text { godina }\end{array}$ & & & \\
\hline Estonija & $\begin{array}{l}\text { Automatski } \\
\text { raspored u } \\
\text { konzervativni fond, } \\
\text { bez ograničenja na } \\
\text { dob }(\mathrm{C})\end{array}$ & & & & \\
\hline Poljska & $\begin{array}{l}\text { Muškarci i žene } \\
\text { do } 55 \text { godina }\end{array}$ & $\begin{array}{l}\text { Muškarci i žene } \\
\text { od } 55 \text { godina - sve } \\
\text { daljnje uplate idu } \\
\text { u C, a imovina se } \\
\text { postepeno dva } \\
\text { puta godišnje } \\
\text { prebacuje u C }\end{array}$ & & & \\
\hline
\end{tabular}

Izvor: Impavido et al. (20Iо.) za Čile, Meksiko i Peru; Arthur (2009.) za Mađarsku, Slovačku i Estoniju; i Wojcieh (20II.) za Poljsku.

Automatski raspored osiguranika u Čileu, Meksiku, Peru, Poljskoj i Mađarskoj baziran je na nekom obliku cjeloživotnog modeliranja, a ograničenje trajanja članstva u pojedinom fondu odnosi se na dob osiguranika. S druge strane, u Estoniji ne postoji ograničenje trajanja članstva obzirom na dob osiguranika, a ukoliko se osiguranik sam ne odluči izabrati kategoriju fonda bit će automatski učlanjen u konzervativni fond. Slovačka nema automatski odabir kategorije fonda za osiguranike, već se osiguranici sami moraju odlučiti za kategoriju fonda, ukoliko žele sudjelovati u sustavu (Arthur, 2009.).

U Hrvatskoj je zamjenski cjeloživotni model ulaganja uveden 20I4. godine (Zakon o obveznim mirovinskim fondovima, 20I4.), a dizajniran je putem formiranja tri mirovinska fonda različitih profila rizičnosti, tj. različitih kategorija: A, B i C. Ograničenja ulaganja u dionice i alternativne investicijske fondove za fondove različitih kategorija dani su u tablici 3. Sukladno navedenim ograničenjima možemo ustvrditi da je fond kategorije A po strategiji ulaganja balansiranog, fond kategorije $\mathrm{B}$ umjereno konzervativnog, a fond kategorije $\mathrm{C}$ konzervativnog profila rizičnosti.

\section{TABLICA 3.}

Maksimalna izloženost mirovinskih fondova kategorija A, B i C u Hrvatskoj u dionice i alternativne investicijske fondove

\begin{tabular}{lccc} 
Vrsta imovine & A & B & C \\
\hline Dionice & $55 \%$ & $35 \%$ & $0 \%$ \\
\hline Alternativni investicijski fondovi & $15 \%$ & $10 \%$ & $0 \%$ \\
\hline
\end{tabular}


Automatski prelazak iz fonda kategorije A $\mathrm{u}$ fond kategorije B događa se $\mathrm{u}$ trenutku kad osiguranik ima manje od Io godina do ostvarivanja prava na mirovinsko osiguranje, dok se sljedeći automatski prelazak događa kada osiguranik ima manje od 5 godina do ostvarivanja prava na mirovinsko osiguranje. Također, osiguranik može promijeniti kategoriju fonda samo u godinama kada napuni godine života koje su višekratnik broja tri te samo u kalendarskom mjesecu u kojemu je rođen. Na taj način onemogućava se prelazak većeg broja članova u fond druge kategorije u slučaju pada cijena na tržištima kapitala obzirom na očekivane prelaske osiguranika $u$ fondove nižeg profila rizičnosti $u$ takvim trenucima. Međutim, navedeni mehanizam ne sprečava prelaske osiguranika koji ispunjavaju uvjete za prelazak te postoji rizik promjene kategorije fonda u takvom nepovoljnom trenutku.

\section{PARAMETARSKI MODEL ZA IZRAČUN AKUMULIRANE ŠTEDNJE U ZAMJENSKOM GJELOŽIVOTNOM MODELU ULAGANJA}

U ovom poglavlju predstavit ćemo nadogradnju parametarskog modela za izračun ukupnih akumuliranih sredstava u II. stupu (Šorić, 200o.) koji je prilagođen zamjenskom cjeloživotnom modelu ulaganja. U takvom aproksimativnom modelu, koji pretpostavlja uplate doprinosa $\mathrm{u}$ jednakim vremenskim intervalima, na ukupni iznos akumuliranih sredstava utječe svega nekoliko faktora: duljina štednje u svakoj od kategorija mirovinskog fonda, prinosi pojedinog mirovinskog fonda, te stopa rasta bruto plaća za koju pretpostavljamo da je jednaka kroz ukupno vrijeme štednje.

Za slučaj štednje u dosadašnjem modelu II. stupa, gdje osiguranik štedi $n$ godina u mirovinskom fondu čiji očekivani realni prinos na dugi rok iznosi $p$ na godišnjoj razini te čija očekivana realna stopa rasta bruto plaće na dugi rok iznosi $i$ na godišnjoj razini, pokazuje se da očekivani ukupni iznos akumuliranih sredstava M iznosi (Šorić, 200o.):

$$
M=R \cdot \frac{r-1}{r^{1 / 12}-1} \cdot \frac{r^{n}-s^{n}}{r-s},
$$

gdje je $R$ trenutni iznos doprinosa za II. stup koji je isplaćen na kraju mjeseca, a $r$ i $s$ indeksi za prinos fonda i stopu rasta bruto plaće:

$$
r=1+p, s=1+i .
$$

Također, pretpostavit ćemo da je doprinos $R$ jednak jedinici te da je isti već umanjen za ulaznu naknadu fonda. Detaljni utjecaj pojedinih parametara na ukupna ušteđena sredstva iz II. stupa opisan je u radu Latković i Liker (2009.).

Izračun ukupno ušteđenih sredstava u zamjenskom cjeloživotnom modelu nešto je složeniji obzirom na tri razdoblja štednje proizvoljnog trajanja s različitim očekivanim prinosima mirovinskih fondova u pojedinim fazama. Stoga kod izračuna očekivane ukupne akumulirane štednje promatramo posebno akumulirana sredstva u pojedinim kategorijama fondova te uvodimo sljedeće oznake:

$M_{i}$... akumulirana sredstva od početka štednje do izlaska iz fonda kategorije $i$, gdje $i$ predstavlja oznaku kategorije fonda (A, B ili C),

$t_{\mathrm{o}}$... dob osiguranika u trenutku ulaska u mirovinski sustav,

$t_{\mathrm{I}} \ldots$ dob osiguranika $\mathrm{u}$ trenutku prelaska iz fonda $\mathrm{A} \mathrm{u}$ fond $\mathrm{B}$,

$t_{2} \ldots$ dob osiguranika $\mathrm{u}$ trenutku prelaska iz fonda $\mathrm{B} \mathrm{u}$ fond $\mathrm{C}$,

$\mathrm{T}$... dob osiguranika u trenutku izlaska iz mirovinskog sustava,

$t_{\mathrm{A}} \ldots$ vrijeme štednje $\mathrm{u}$ fondu kategorije $\mathrm{A}$,

$t_{B} \ldots$ vrijeme štednje $u$ fondu kategorije $B$, 
$t_{\mathrm{C}} \ldots$ vrijeme štednje $\mathrm{u}$ fondu kategorije $\mathrm{C}$,

$p_{i} \ldots$ prosječni godišnji prinos fonda kategorije $i$,

$r_{i}=1+p_{i} \ldots$ indeks za stopu prinosa fonda kategorije $i$,

$r_{i m}=r_{i}^{1 / 12} \ldots$ indeks za stopu mjesečnog prinosa fonda kategorije $i$.

Sukladno jednadžbi (3.I) očekivana akumulirana sredstva u fondu A na kraju razdoblja štednje u tom fondu iznose:

$$
M_{A}=\frac{r_{A}-1}{r_{A}{ }^{1 / 12}-1} \cdot \frac{r_{A}^{t_{A}-s_{A} t_{A}}}{r_{A^{-S}}}
$$

Kada osiguranik navrši $t_{\mathrm{I}}$ godina, prelazi iz fonda A u fond B te se njegovi doprinosi počinju uplaćivati $\mathrm{u}$ fond B. Istovremeno, dotad akumulirana sredstva iz fonda A predstavljaju jednokratnu uplatu u fond $B$, te se ona u ukupnom iznosu ukamaćuje po očekivanom prinosu fonda B sve do trenutka izlaska iz fonda $\mathrm{B}$, to jest sve do trenutka $t_{2}$. Očekivana akumulirana sredstva u fondu B na kraju razdoblja štednje u tom fondu iznose:

$$
M_{B}=M_{A} \cdot r_{B}^{t_{B}}+s^{t_{A}} \cdot \frac{r_{B}-1}{r_{B}{ }^{1 / 12}-1} \cdot \frac{r_{B}^{t_{B}}-s^{t_{B}}}{r_{B}-s} .
$$

Analogno prethodno navedenom, očekivana akumulirana sredstva u fondu C na kraju razdoblja štednje u tom fondu iznose:

$$
M_{C}=M_{B} \cdot r_{C}^{t_{C}}+s^{\left(t_{2}-t_{0}\right)} \cdot \frac{r_{C-1}}{r_{C} C^{1 / 12}-1} \cdot \frac{r_{C}^{t_{C}-s^{t} C}}{r_{C}-s}
$$

Nakon što se izrazi (3.3) i (3.4) uvrste u jednadžbu (3.5), dobiva se sljedeći izraz za očekivani ukupni iznos akumuliranih sredstava, $M_{P L C}$, $u$ zamjenskom cjeloživotnom modelu ulaganja:

$$
M_{P L C}=\frac{r_{A}-1}{r_{A}{ }^{1 / 12}-1} \cdot \frac{r_{A}^{t_{A}-s^{t}}}{r_{A}-s} \cdot r_{B}^{t_{B}} \cdot r_{C}^{t_{C}}+s^{t_{A}} \cdot \frac{r_{B}-1}{r_{B}{ }^{1 / 12}-1} \cdot \frac{r_{B}^{t_{B}-s^{t_{B}}}}{r_{B}-s} \cdot r_{C}^{t_{C}}+s^{\left(t_{2}-t_{0}\right)} \cdot \frac{r_{C}-1}{r_{C} C^{1 / 12}-1} \cdot \frac{r_{C}^{t_{C}}-s^{t_{C}}}{r_{C}-s}
$$

Navodimo i posebne slučajeve jednadžbe (3.6) kada osiguranik provodi cijelo vrijeme $u$ fondu kategorije $\mathrm{A}\left(t_{\mathrm{I}}=t_{2}=\mathrm{T}\right)$ :

$$
M_{P L C}^{A}=\frac{r_{A}-1}{r_{A}^{1 / 12}-1} \cdot \frac{r_{A}^{\left(T-t_{0}\right)}-S^{\left(T-t_{0}\right)}}{r_{A}-S},
$$

kada osiguranik provodi cijelo vrijeme $u$ fondu kategorije $\mathrm{B}\left(t_{\mathrm{o}}=t_{\mathrm{I}} ; t_{2}=\mathrm{T}\right)$ :

$$
M_{P L C}^{B}=\frac{r_{B}-1}{r_{B}{ }^{1 / 12}-1} \cdot \frac{r_{B}^{\left(T-t_{0}\right)}-s^{\left(T-t_{0}\right)}}{r_{B}-s},
$$

te kada osiguranik provodi cijelo vrijeme $\mathrm{u}$ fondu kategorije $\mathrm{C}\left(t_{\mathrm{o}}=t_{\mathrm{I}}=t_{2}\right)$ :

$$
M_{P L C}^{C}=\frac{r_{C}-1}{r_{C}{ }^{1 / 12}-1} \cdot \frac{r_{C}^{\left(T-t_{0}\right)}-s^{\left(T-t_{0}\right)}}{r_{C}-s} .
$$

U nastavku ćemo radi jednostavnosti pretpostaviti da nema realnog rasta bruto plaća što dodatno pojednostavljuje jednadžbe za očekivane iznose akumuliranih sredstava dane jednadžbama (3.3) do (3.9). Navedenu pretpostavku možemo opravdati činjenicom da je, za slučaj realne stope rasta bruto plaća veće od nule koja se kreće u rasponu prosječnih povijesnih realnih stopa rasta bruto plaća $u$ Hrvatskoj, analiza pokazala analogne rezultate. 


\section{OČEKIVANI PRINOSI I RIZIGI MIROVINSKIH FONDOVA RAZLIČITIIH KATEGORIJA}

Kako bismo mogli usporediti izračun ukupno akumuliranih sredstava prema dosadašnjem i novom zakonu te odrediti očekivane rizike, u nastavku ćemo definirati očekivane dugoročne prinose osnovnih klasa imovine koji čine portfelje mirovinskih fondova pojedinih kategorija te njihove rizičnosti i međusobne korelacije.

Očekivani dugoročni prinosi mirovinskih fondova najviše ovise o strateškoj alokaciji njihovih portfelja, tj. o omjeru između dužničkih vrijednosnih papira (obveznica) i vlasničkih vrijednosnih papira (dionica) u portfelju. Uz pomoć prosječnih ostvarenih prinosa na duži rok za te dvije osnovne klase imovine moguće je postaviti očekivanja za njihove buduće vrijednosti. Isto se odnosi i na očekivane rizičnosti te korelacije.

Analizom kretanja povijesnih prinosa obveznica i dionica na razvijenim tržištima kapitala (Dimson et al., 2OI4.) moguće je pretpostaviti iznose očekivanih prinosa i rizika za ta tržišta, ali i dati procjenu očekivanih prinosa i rizika za hrvatsko tržište kapitala (tablica 4.). Obzirom na kratku povijest domaćeg dioničkog tržišta kapitala i nemogućnost statističkih procjena prosječnih povijesnih prinosa, za hrvatsko dioničko tržište kapitala koristimo procjene za očekivane prinose (Latković i Liker, 2009.) koji su bazirani na osnovu razlike u povijesnim prinosima između tržišta u nastajanju (I2,5\%) i razvijenih tržišta (Io,8\%) ostvarenih nakon 2. svjetskog rata do danas (Dimson et al., 20I4.). Stoga za očekivani realni prinos za dionice na domaćem tržištu kapitala uzimamo povijesni realni prinos za inozemno tržište dionica uvećan za premiju od 2 postotna boda. Obzirom da razliku u premiji između obveznica na tržištima u nastajanju i razvijenih tržišta nije moguće ocijeniti na duži rok (povijest izdavanja duga u stranoj valuti za tržišta u nastajanju počinje tek početkom 9o-tih godina prošlog stoljeća), pretpostavljamo da ista treba biti manja od razlike u dioničkim premijama zbog općenito manjeg rizika obveznica spram dionica. Stoga smo radi jednostavnosti procijenili da bi se realni prinos obveznica za inozemno tržište trebao uvećati za I postotni bod kako bi se dobio očekivani realni prinos na domaće obvezničko tržište. Rezultati provedenih analiza u ovome radu ovise samo kvantitativno o konkretnim procjenama očekivanih prinosa za hrvatsko tržište kapitala, ali ne i kvalitativno sve dok su premije za hrvatsko tržište veće od odgovarajućih premija za razvijena tržišta kapitala. Očekivani rizici za inozemna dionička i obveznička tržišta procijenjeni su na osnovu povijesnih volatilnosti (Dimson et al., 20I4.) dok je za hrvatsko tržište uzeta vrijednost povijesnih volatilnosti za tržišta u nastajanju. Pretpostavke o korelacijama koje ćemo koristiti dalje u analizi dane su u tablici 5., a dobivene su promatranjem trendova u kretanju korelacija prinosa na pojedine klase imovine.

\section{TABLICA 4.}

Očekivani prinosi i rizici za osnovne klase ulaganja na domaćem i inozemnim tržištima kapitala (\% na godišnjem nivou)

\begin{tabular}{|c|c|c|}
\hline Klasa imovine & Očekivani realni prinos & Očekivani rizik \\
\hline HR obvezničko tržište & 2,8 & IO \\
\hline HR dioničko tržište & 7,2 & 27 \\
\hline INO obvezničko tržište & $\mathrm{I}, 8$ & 7 \\
\hline INO dioničko tržište & 5,2 & I8 \\
\hline
\end{tabular}

Izvor: Dimson et al. (20I4.) te izračuni autora. 
TABLICA 5.

Pretpostavke korelacija osnovnih klasa ulaganja na domaćem i inozemnim tržištima kapitala

\begin{tabular}{lcccc} 
Korelacije & HR O & HR D & INO O & INO D \\
\hline HR obvezničko tržište & I & O,25 & O,3 & O,2 \\
\hline HR dioničko tržište & O,25 & I & O,I & O,6 \\
\hline INO obvezničko tržište & O,3 & O,I & I & 0,2 \\
\hline INO dioničko tržište & 0,2 & 0,6 & 0,2 & I
\end{tabular}

Izvor: izračuni autora.

Uzimajući u obzir zakonske limite za ulaganja u dionice mirovinskih fondova različitih kategorija (tablica 3.), pretpostavit ćemo ciljanu alokaciju imovine fondova A, B i C u dionice i obveznice te definirati ciljanu alokaciju mirovinskog fonda po dosadašnjem zakonu na osnovu povijesnih ulaganja obveznih mirovinskih fondova u Hrvatskoj u dionice i obveznice u razdoblju od kraja 2006. do kraja 20I3. godine (izvor: HANFA). Pretpostavke o alokacijama prikazane su u tablici 6.

\section{TABLICA 6.}

Pretpostavljena alokacija mirovinskih fondova u dionice i obveznice (\% neto imovinske vrijednosti fonda)

\begin{tabular}{lcccc} 
& Dosadašnji zakon & A & B & C \\
\hline Dioničko tržište & 25 & 50 & 25 & 0 \\
\hline Obvezničko tržište & 75 & 50 & 75 & IOO
\end{tabular}

Primijetimo da je umjereno konzervativna alokacija imovine fonda kategorije B identična alokaciji imovine mirovinskih fondova po dosadašnjem zakonu. Za fond kategorije A odabrana je balansirana alokacija imovine, dok je alokacija fonda kategorije $\mathrm{C} u$ potpunosti konzervativna. Nadalje, pretpostavimo još da će fondovi imovinu ulagati na hrvatsko i inozemno tržište prema alokaciji IO prikazanoj u tablici 7.

\section{TABLICA 7.}

Pretpostavljena alokacija mirovinskih fondova prema tržištima ( \% neto imovinske vrijednosti fonda)

\begin{tabular}{|c|c|c|c|c|}
\hline & Dosadašnji zakon & $\mathbf{A}$ & B & $\mathbf{C}$ \\
\hline HR obvezničko tržište & 65 & 40 & 65 & 90 \\
\hline HR dioničko tržište & I5 & 30 & I5 & $\mathrm{O}$ \\
\hline INO obvezničko tržište & IO & IO & IO & IO \\
\hline INO dioničko tržište & IO & 20 & IO & $\mathrm{o}$ \\
\hline
\end{tabular}

Na osnovu danih pretpostavki o očekivanim realnim prinosima, rizicima, korelacijama te alokacijama imovina $u$ portfeljima mirovinskih fondova prikazanih $u$ tablicama 4. do 7. možemo uz pomoć jednadžbi za ukupni prinos, $R_{P}$, i rizik portfelja, $\sigma_{P}$ :

$$
\begin{aligned}
R_{P} & =\sum_{i} w_{i} R_{i}, \\
\sigma_{P}^{2} & =\sum_{i, j} w_{i} w_{j} \sigma_{i} \sigma_{j} \rho_{i j},
\end{aligned}
$$

gdje su $w_{i}$ udjeli pojedinih klasa imovine u portfelju, $R_{i}$ očekivani prinosi pojedinih klasa, $\sigma_{i}$ očekivani rizici pojedinih klasa te $\rho_{i j}$ očekivane korelacije između pojedinih klasa, izračunati očekivane realne prinose i rizike za svaki pojedini fond. U tablici 8. prikazani su dobiveni rezultati. 


\section{TABLICA 8.}

Očekivani realni prinosi i rizici mirovinskih fondova prema dosadašnjem i novom zakonu ( \% na godišnjem nivou)

\begin{tabular}{|ccccc} 
& Dosadašnji zakon & A & B & G \\
\hline Očekivani realni prinos & 3,60 & 4,50 & 3,60 & 2,70 \\
\hline Očekivani rizik & 9,63 & 12,48 & 9,63
\end{tabular}

Rezultati prikazani u tablici 8. pokazuju da su očekivani realni prinosi i rizici najveći za fond kategorije A te da sa smanjenjem udjela dionica u portfeljima fondova kategorija B i C očekivani realni prinosi i rizici opadaju. Rezultati za mirovinski fond po dosadašnjem zakonu i fond kategorije B su identični obzirom na istu pretpostavljenu alokaciju imovine. Međutim, uočimo da smanjenje očekivane rizičnosti fonda kategorije $\mathrm{C} u$ odnosu na fond kategorije $\mathrm{B}$ nije proporcionalno smanjenju očekivane rizičnosti fonda kategorije B u odnosu na fond kategorije A usprkos proporcionalnom smanjenju alokacije u dionice. Očekivana rizičnost fonda kategorije B manja je za 22,8\% u odnosu na očekivanu rizičnost fonda kategorije $\mathrm{A}$, dok je očekivana rizičnost fonda kategorije $\mathrm{C}$ manja za svega 4,I\% u odnosu na očekivanu rizičnost fonda kategorije B.

Razlog tome je prvenstveno nedovoljna diverzifikacija ulaganja $\mathrm{u}$ fondu kategorije $\mathrm{C}$ uzrokovana velikim udjelom hrvatskih obveznica u portfelju u iznosu od 90\%. Smanjenjem udjela hrvatskih obveznica na $80 \%$ te povećanjem udjela inozemnih obveznica na $20 \%$ u fondu kategorije C dobiva se smanjenje očekivane rizičnosti za II,5\% uz smanjenje i očekivanog realnog prinosa, ali za svega desetinu postotnog boda. U slučaju kada bi se dopustilo ulaganje u dionice za fond kategorije $\mathrm{C}$ te uz pretpostavku ciljane alokacije $\mathrm{u}$ taj segment $\mathrm{u}$ iznosu od Io\% (5\% u hrvatske dionice i $5 \% \mathrm{u}$ inozemne dionice), uz odgovarajuću realokaciju ulaganja u obveznice u iznosu od $75 \%$ za hrvatske obveznice i I5\% za inozemne obveznice, očekivana rizičnost bila bi neznatno veća nego u prethodnom slučaju uz njezino smanjenje za Io,3\% u odnosu na rizičnost fonda kategorije C s alokacijom 9o/ıo u domaće i inozemne obveznice. Također, očekivani realni prinos raste na 3\% što je za o,3 postotna boda veći iznos od očekivanog realnog prinosa fonda kategorije $\mathrm{C}$, a alokacijom 9o/ro samo u obveznice.

Iz navedenog možemo zaključiti da diverzifikacijski učinak različitih klasa imovine vjerojatno nije u potpunosti iskorišten za fond kategorije $\mathrm{C}$ te da se neznatnim povećanjem alokacije $\mathrm{u}$ dionička tržišta može dobiti veće smanjenje rizičnosti uz istovremeno povećanje profita. Međutim, iznos smanjenja rizičnosti prije svega ovisi o procjenama alokacije imovine mirovinskih fondova, rizičnosti pojedinih klasa imovine kao i o njihovim međusobnim korelacijama te stoga tako dobivene iznose smanjenja rizika treba shvatiti više kao indikaciju (ali ne i kvantifikaciju) nedostatka diverzifikacije za fond kategorije C.

\section{OČEKIVANA UKUPNA AKUMULIRANA SREDSTVA I UTJEGAJ TRŽIŠNOG ŠOKA}

U nastavku ćemo analizirati iznose očekivanih ukupnih akumuliranih sredstava u zamjenskom cjeloživotnom modelu ulaganja dobivenih na osnovu očekivanih prinosa mirovinskih fondova različitih kategorija te usporediti s mirovinskim fondom po dosadašnjem zakonu. Dodatne pretpostavke koje unosimo $\mathrm{u}$ analizu su ukupno trajanje akumulacijske faze te trajanja štednje $\mathrm{u}$ pojedinim kategorijama fondova A, B i C. Pretpostavit ćemo da osiguranik počinje ostvarivati prava na mirovinsko osiguranje s 25 godina života te da u mirovinu odlazi sa 65 godina života, tj. da će ostvariti ukupno 40 godina mirovinskog staža. Zanima nas koliko će se mijenjati očekivana ukupna 
akumulirana sredstva, $M_{P L C}$, obzirom na promjenu dobi osiguranika u trenutku prelaska iz fonda $\mathrm{A} \mathrm{u}$ fond $\mathrm{B}, t_{\mathrm{I}}$, tj. obzirom na promjenu dobi osiguranika $\mathrm{u}$ trenutku prelaska iz fonda $\mathrm{B} u$ fond $\mathrm{C}, t_{2}$, te koliko će ta mirovina iznositi u odnosu na očekivana ukupna akumulirana sredstva prema dosadašnjem zakonu, $M$.

Također, zanima nas i utjecaj tržišnog šoka na iznos tih sredstava na kraju akumulacijske faze, tj. izračun graničnog gubitaka kod kojeg je vjerojatnost opažanja većeg gubitka od navedenog manja od unaprijed zadane vjerojatnosti (Scheuenstuhl et al., 20Io.). Navedeni koncept naziva se Value-at-Risk (VaR) portfelj, a definira se kao:

$$
P(L>\mathrm{VaR}) \leq 1-c,
$$

gdje je $c$ nivo pouzdanosti, a L očekivani gubitak fonda. Zbog jednostavnosti pretpostavit ćemo da su promjene prinosa mirovinskog fonda nezavisne i jednako distribuirane normalne slučajne varijable.

$\mathrm{Na}$ osnovu pretpostavke da će akumulacijska faza trajati 40 godina te uz pretpostavku o jednom izoliranom tržišnom šoku $u$ tih 40 godina, definiramo nivo pouzdanosti $c=\mathrm{I}-\mathrm{I} / 4 \mathrm{O}=97,5 \%$, tj. određujemo vjerojatnost od 2,5\% za pojavu gubitka većeg od VaR-a. Primjer takvog događaja na tržištima kapitala dogodio se 2008. godine kada je pad inozemnih dioničkih tržišta mjereno indeksom MSCI World (s uključenim dividendnim prinosom) iznosio 37,25\% mjereno u kunama, dok je pad domaćeg dioničkog tržišta mjereno indeksom CROBEX iznosio 63,74\%. Prosječni pad prinosa obveznih mirovinskih fondova u 2008. godini mjereno indeksom MIREX iznosio je 12,50\%. Prema pretpostavkama iz tablice 7. i tablice 8. granični gubitak definiran formulom (5.I) za fond prema dosadašnjem zakonu iznosi I5,28\% i usporediv je s prosječnim ostvarenim padom MIREX-a u 2008. godini.

Za slučaj normalno raspodijeljenih prinosa mirovinskog fonda i nivo pouzdanosti od 97,5\%, očekivani VaR fonda iznosi:

$$
\mathrm{VaR}=M \cdot\left(1,96 \cdot \sigma_{P}-R_{P}\right),
$$

gdje su $R_{P} \mathrm{i} \sigma_{\mathrm{P}}$ očekivani prinos i rizik fonda, a $M$ očekivana ukupno akumulirana sredstava. Ovaj izraz nam omogućava da odredimo gubitak koji bi proistekao iz tržišnog šoka u trenutku umirovljenja.

\section{TABLICA 9.}

\begin{tabular}{|c|c|c|c|c|}
\hline & $\begin{array}{l}\text { Očekivani realni } \\
\text { prinos }(\%)\end{array}$ & $\begin{array}{c}\text { Očekivani rizik } \\
(\%)\end{array}$ & $\begin{array}{l}\text { Očekivana ukupno } \\
\text { akumulirana sredstva }(\mathbf{k n})\end{array}$ & $\begin{array}{r}\text { VaR } \\
(\mathbf{k n})\end{array}$ \\
\hline Dosadašnji zakon & 3,6 & 9,63 & I.055,4 & I6I,3 \\
\hline Samo fond A & 4,5 & $\mathrm{I} 2,48$ & I.3IO, 6 & $26 \mathrm{I}, 7$ \\
\hline Samo fond B & 3,6 & 9,63 & I.055,4 & I6I,3 \\
\hline Samo fond C & 2,7 & 9,23 & $856, \mathrm{I}$ & I3I, 8 \\
\hline A-B-C shema* & 4,I6 & 9,23 & I.I57,6 & I6I,4 \\
\hline B-C shema** & 3,49 & 9,23 & I.OII,7 & 147,8 \\
\hline Cjeloživotni model & $3, \mathrm{OI}$ & $8,5 \mathrm{I}$ & I.I39,3 & I55,7 \\
\hline
\end{tabular}

Izračun očekivanih ukupno akumuliranih sredstava i VaR-a za jediničnu uplatu

* Prosječni očekivani realni prinos sukladno vremenima štednje u fondovima A, B i C te očekivani rizik za fond C.

** Prosječni očekivani realni prinos sukladno vremenima štednje u fondovima B i C te očekivani rizik za fond C.

Promotrimo slučaj kada bi osiguranik proveo cijeli radni staž u mirovinskom fondu prema dosadašnjem zakonu, $\mathrm{u}$ fondovima pojedine kategorije, uz zakonski uvjetovane prelaske $\mathrm{u}$ zamjenskom cjeloživotnom modelu ulaganja ako sam odluči odabrati fond A na početku štednje (A-B- 
$\mathrm{C}$ shema: prelazak iz fonda A $\mathrm{u}$ fond $\mathrm{B}$ Io godina prije umirovljenja, tj. iz fonda $\mathrm{B} u$ fond $\mathrm{C} 5$ godina prije umirovljenja) te ako na početku štednje odluči ostati u B (B-C shema: prelazak iz fonda B u fond C 5 godina prije umirovljenja). Dobiveni rezultati za očekivana ukupno akumulirana sredstava i pripadni VaR prikazani su u tablici 9.

Vidimo da bi očekivana ukupna akumulirana sredstava za slučaj kada bi osiguranik mogao provesti ukupni radni staž u fondu A bila najveća, no isto tako bi bio najveći i očekivani rizik te očekivani VaR. Osiguranik u svakom slučaju može odabrati da cjelokupni staž provede u fondu $\mathrm{C}$, gdje je očekivani rizik najmanji, ali uz značajnu penalizaciju očekivanih ukupno akumuliranih sredstava. Zamjenski cjeloživotni model ulaganja omogućava osiguraniku da ostvari u prosjeku prinos koji je veći od prinosa fonda na osnovu dosadašnjeg zakona te prinosa da je bio samo član fonda B ili samo fonda C. Međutim, njegov očekivani rizik u trenutku umirovljenja dan je upravo rizičnošću fonda C dok je VaR gotovo identičan VaR-u fonda po dosadašnjem zakonu. Dakle, čak i u slučaju tržišnog šoka u trenutku umirovljenja, osiguranik bolje prolazi u zamjenskom cjeloživotnom modelu ulaganja (A-B-C shema) nego u slučaju ulaganja po dosadašnjem zakonu. U slučaju da se u zamjenskom cjeloživotnom modelu osiguranik ne odluči na članstvo $\mathrm{u}$ fondu $\mathrm{A}$, tj. odabere ili biva raspoređen po zakonu $\mathrm{u}$ fond $\mathrm{B}$, te ostane član fonda B sve do zakonskog ograničenja članstva (B-C shema; prelazak iz fonda B u fond C 5 godina prije umirovljenja), može očekivati manji iznos ukupnih akumuliranih sredstava te manji VaR od onoga prema dosadašnjem zakonu. U slučaju tržišnog šoka u trenutku umirovljenja, osiguranik bi u ovom slučaju bolje prošao prema ulaganjima iz dosadašnjeg zakona.

U nastavku ćemo analizirati i jedan od cjeloživotnih modela ulaganja i dati usporedbu sa zamjenskim cjeloživotnim modelom u Hrvatskoj. U drugom poglavlju spomenuli smo da postoji više načina provođenja cjeloživotnog modeliranja portfelja. Istraživanja pokazuju da postoji dob osiguranika do koje on treba biti gotovo u cijelosti izložen dioničkom tržištu, a nakon te dobi udio ulaganja u dionice se treba postepeno smanjivati sve do trenutka umirovljenja (Schiller, 2006.). Neki od mogućih scenarija cjeloživotnog modeliranja portfelja daju sljedeće omjere ulaganja u dioničko i obvezničko tržište:

- osnovni portfelj: početna alokacija u dionice iznosi $85 \%$ imovine fonda i zadržava se sve dok osiguranik ne navrši 29 godina, a nakon toga udio ulaganja u dionice se postepeno smanjuje prema $15 \%$ do trenutka umirovljenja,

- konzervativni obveznički portfelj: slično kao i osnovni portfelj, samo je početno ulaganje u dionice $70 \%$, a završno I0\%,

- agresivni portfelj: slično kao i osnovni portfelj, samo je početno ulaganje u dionice 90\%, a završno $40 \%$.

Od ova tri scenarija odabrat ćemo konzervativni obveznički portfelj za analizu obzirom da isti najbliže opisuje A-B-C shemu ulaganja u Hrvatskoj. Zbog jednostavnosti izračuna alokaciju dionica i obveznica linearno ćemo smanjivati od trenutka kada osiguranik navrši 29 godina pa sve do trenutka njegovog umirovljenja. Također, pretpostavit ćemo fiksne omjere između ulaganja u hrvatsko i inozemno tržište i to 4:I za obveznice i 3:2 za dionice za cijelo vrijeme ulaganja (u početnom trenutku alokacija iznosi $42 \% \mathrm{u}$ hrvatske dionice, $28 \% \mathrm{u}$ inozemne dionice, $24 \% \mathrm{u}$ hrvatske obveznice i $6 \% \mathrm{u}$ inozemne obveznice). Rezultat za ovakav odabir cjeloživotnog modela ulaganja prikazan je u tablici 9 . Iz prikazanih rezultata vidimo da je zamjenski cjeloživotni model ulaganja u Hrvatskoj usporediv s odabranim dinamičkim cjeloživotnim modelom ulaganja kako po akumuliranim sredstvima, tako i po iznosu VaR-a. 


\section{RIZIK PROMJENE KATEGORIJE FONDA U NEPOVOLJNOM TRENUTKU}

Kao što smo u uvodu napomenuli, pravilan odabir vremena prelaska iz mirovinskog fonda veće rizičnosti $\mathrm{u}$ fond manje rizičnosti je bitan faktor kod određivanja očekivanog iznosa ukupno akumuliranih sredstava $u$ zamjenskom cjeloživotnom modelu ulaganja $u$ II. stupu. U ovom radu nećemo se baviti optimiziranjem tog procesa $u$ svrhu ostvarivanja maksimalnog iznosa ukupno akumuliranih sredstava $u$ odnosu na rizik u trenutku završetka akumulacijske faze, već ćemo se posvetiti analizi scenarija svojevoljnog prelaska osiguranika $u$ fond manje rizičnosti $u$ nepovoljnom trenutku.

U nastavku nepovoljni trenutak prelaska u fond manje rizičnosti predstavlja scenarij gdje nakon tržišnog šoka osiguranik, koji neposredno nakon pojave tržišnog šoka može promijeniti kategoriju fonda, odluči prenijeti dotad akumulirana sredstva u fond manje rizičnosti. Očekivanje za ostvarenje takvog scenarija temeljimo u povećanom broju izlazaka iz dobrovoljnih mirovinskih fondova nakon pada tržišta krajem 2008. godine (prema mjesečnim izvještajima HANFA-e o stanju članstva dobrovoljnih mirovinskih fondova). Nadalje, u svim sljedećim primjerima koristit ćemo zakonska ograničenja na maksimalno vrijeme provedeno $u$ fondu A i minimalno vrijeme provedeno $u$ fondu $\mathrm{B}$, odnosno C. Razloge ovakve inertne dinamike prelazaka iz fonda jedne kategorije $u$ fond druge kategorije nalazimo u dosadašnjoj inertnosti prilikom samostalnog odabira mirovinskog fonda osiguranika koji prvi puta ulaze u sustav obveznog mirovinskog osiguranja, kao i u njihovoj kasnijoj inertnosti da promjene mirovinski fond obzirom na ostvarene rezultate istih.

U analizi ćemo i dalje koristiti očekivanja za pojavu tržišnog šoka jednom u 40 godina, tj. promatrat ćemo VaR uz nivo pouzdanosti od 97,5\%. Tržišni šok portfelja $P$ definirat ćemo kao

$$
S^{P}=1,96 \cdot \sigma_{P}-R_{P},
$$

gdje su $R_{P} i$ $\sigma_{P}$ očekivani prinos i rizik fonda, a $P$ promatrani fond. Tržišne šokove primijenit ćemo na akumulirana sredstva $\mathrm{u}$ fondovima $\mathrm{A}$ ili $\mathrm{B}$ te promatrati kako se ponašaju očekivana ukupno akumulirana sredstva $\mathrm{u}$ trenutku umirovljenja $\mathrm{u}$ ovisnosti o vremenu prelaska iz fonda $\mathrm{A} u \mathrm{~B}$ ili iz fonda B u C (ovisno u kojem fondu se osiguranik trenutno nalazi).

Jednadžbu za očekivana ukupno akumulirana sredstva u zamjenskom cjeloživotnom modelu ulaganja možemo zapisati kao:

$$
M_{P L C}=M^{A}+M^{B}+M^{C}
$$

gdje je:

$$
\begin{aligned}
& M^{A}=R \cdot \frac{r_{A}-1}{r_{A}^{1 / 12}-1} \cdot \frac{r_{A}^{t_{A}}-s^{t_{A}}}{r_{A}-s} \cdot r_{B}^{t_{B}} \cdot r_{C}^{t_{C}}, \\
& M^{B}=R \cdot s^{t_{A}} \cdot \frac{r_{B}-1}{r_{B}{ }^{1 / 12}-1} \cdot \frac{r_{B}^{t_{B}}-s^{t_{B}}}{r_{B}-s} \cdot r_{C}^{t_{C}}, \\
& M^{C}=R \cdot s^{\left(t_{2}-t_{0}\right)} \cdot \frac{r_{C}-1}{r_{C}{ }^{1 / 12}-1} \cdot \frac{r_{C}^{t_{C}}-s^{t_{C}}}{r_{C}-s} .
\end{aligned}
$$

Ako osiguranik koji je član fonda A odluči preći u fond B u nepovoljnom trenutku, tada jednadžba (6.3) postaje:

$$
M_{S}^{A}=R \cdot \frac{r_{A}-1}{r_{A}^{1 / 12-1}} \cdot \frac{r_{A}^{t_{A}-s_{A} t_{A}}}{r_{A^{-S}}} \cdot\left(1-S^{A}\right) \cdot r_{B}^{t_{B}} \cdot r_{C}^{t_{C}}
$$

te njegova očekivana ukupno akumulirana sredstva iznose:

$$
M_{P L C}^{S, A}=M_{S}^{A}+M^{B}+M^{C} .
$$


Analogno, ako osiguranik koji je član fonda B odluči preći u fond $\mathrm{C}$ u nepovoljnom trenutku, tada jednadžba (6.4) postaje:

$$
M_{S}^{B}=R \cdot s^{t_{A}} \cdot \frac{r_{B}-1}{r_{B}{ }^{1 / 12}-1} \cdot \frac{r_{B}^{t_{B}-s^{t_{B}}}}{r_{B}-s} \cdot\left(1-S^{B}\right) \cdot r_{C}^{t_{C}},
$$

te njegova očekivana ukupno akumulirana sredstva iznose:

$$
M_{P L C}^{S, B}=M^{A} \cdot\left(1-S^{B}\right)+M_{S}^{B}+M^{C} .
$$

U nastavku ćemo promotriti iznose očekivanih ukupno akumuliranih sredstava u slučaju nepovoljnog trenutka promjene fonda, te za slučaj kada se šok uopće ne dogodi. Promotrimo situaciju kada se šok dogodi u trenutku prelaska iz fonda A u B. Pretpostavimo da je promjena fonda iz A u B moguća u bilo kojem trenutku.

\section{SLIKA I.}

Očekivana ukupna akumulirana sredstva (za jediničnu uplatu) bez šoka i sa šokom u fondu A

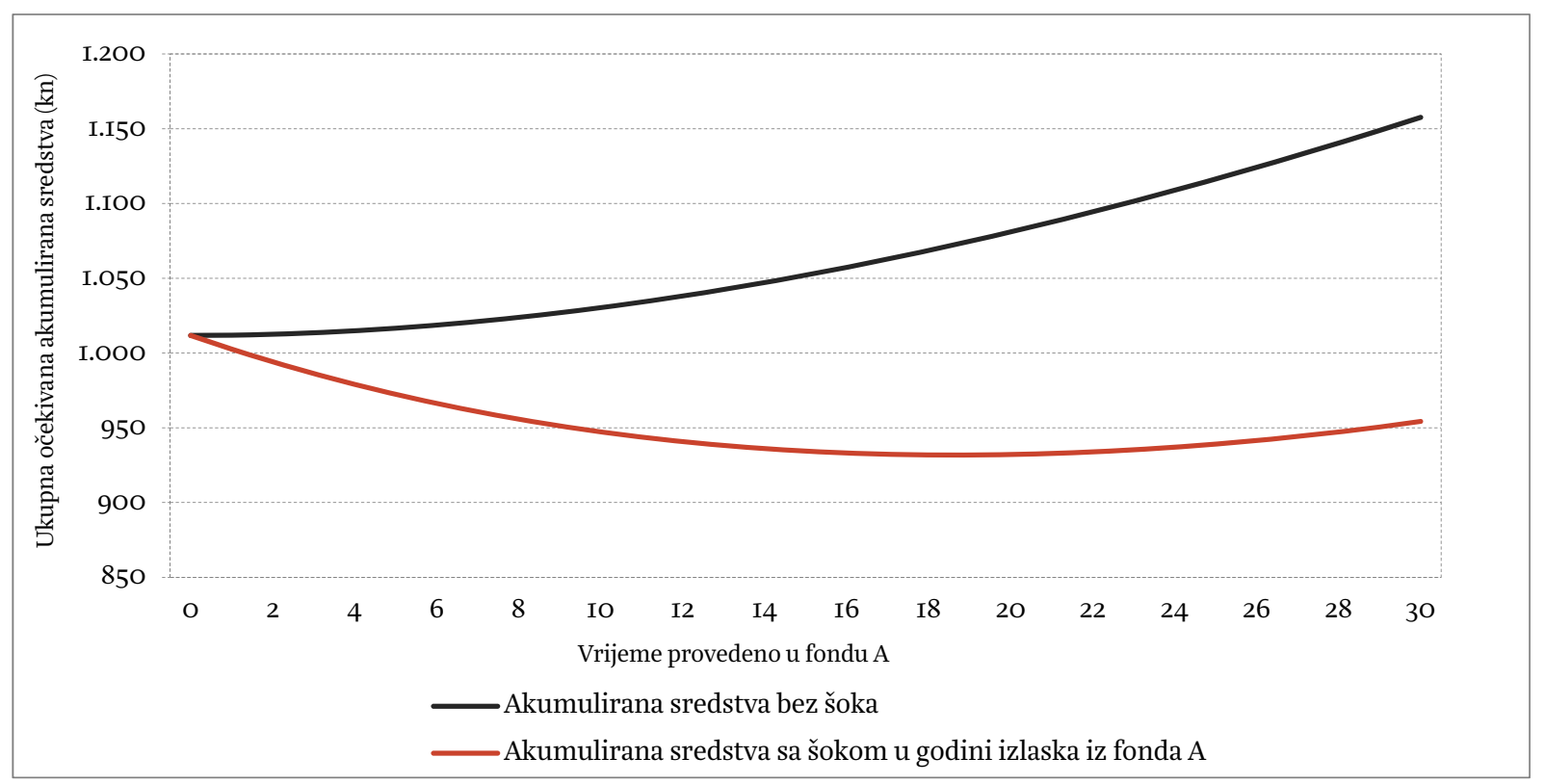

Vidljivo je da šok u trenutku prelaska iz fonda uvelike utječe na iznos očekivanih ukupnih akumuliranih sredstava te da razlika između akumuliranih sredstava bez šoka i sa šokom nakon kojeg član odluči promijeniti fond raste $s$ vremenom provedenim $u$ fondu A. Ako se šok dogodi u početnim godinama ulaganja $\mathrm{u}$ fond $\mathrm{A}$, te se osiguranik rano odluči na prelazak $\mathrm{u}$ fond manje rizičnosti, stvara se oportunitetni trošak, to jest, rizik propuštene zarade (prinosa) koji je mogao ostvariti da je ostao u fondu A. Ovaj oportunitetni trošak raste u početnim godinama ostvarivanja mirovinskog staža, jer je preostalo vrijeme do mirovine u kojem osiguranik više nije član fonda A značajno. U ovom slučaju, otprilike na polovici maksimalnog zakonom predviđenog vremena na trajanje članstva u fondu A, međusobni utjecaj oportunitetnog troška i dotad akumuliranih sredstava rezultira najnižim iznosom ukupnih očekivanih akumuliranih sredstava u slučaju izlaska iz fonda neposredno nakon tržišnog šoka.

Nadalje, promotrimo situaciju kada se šok dogodi u trenutku prelaska iz fonda B u C. Pretpostavimo da je promjena fonda iz B u C moguća u bilo kojem trenutku. 


\section{SLIKA 2.}

Očekivana ukupna akumulirana sredstva (za jediničnu uplatu) bez šoka i sa šokom u fondu B

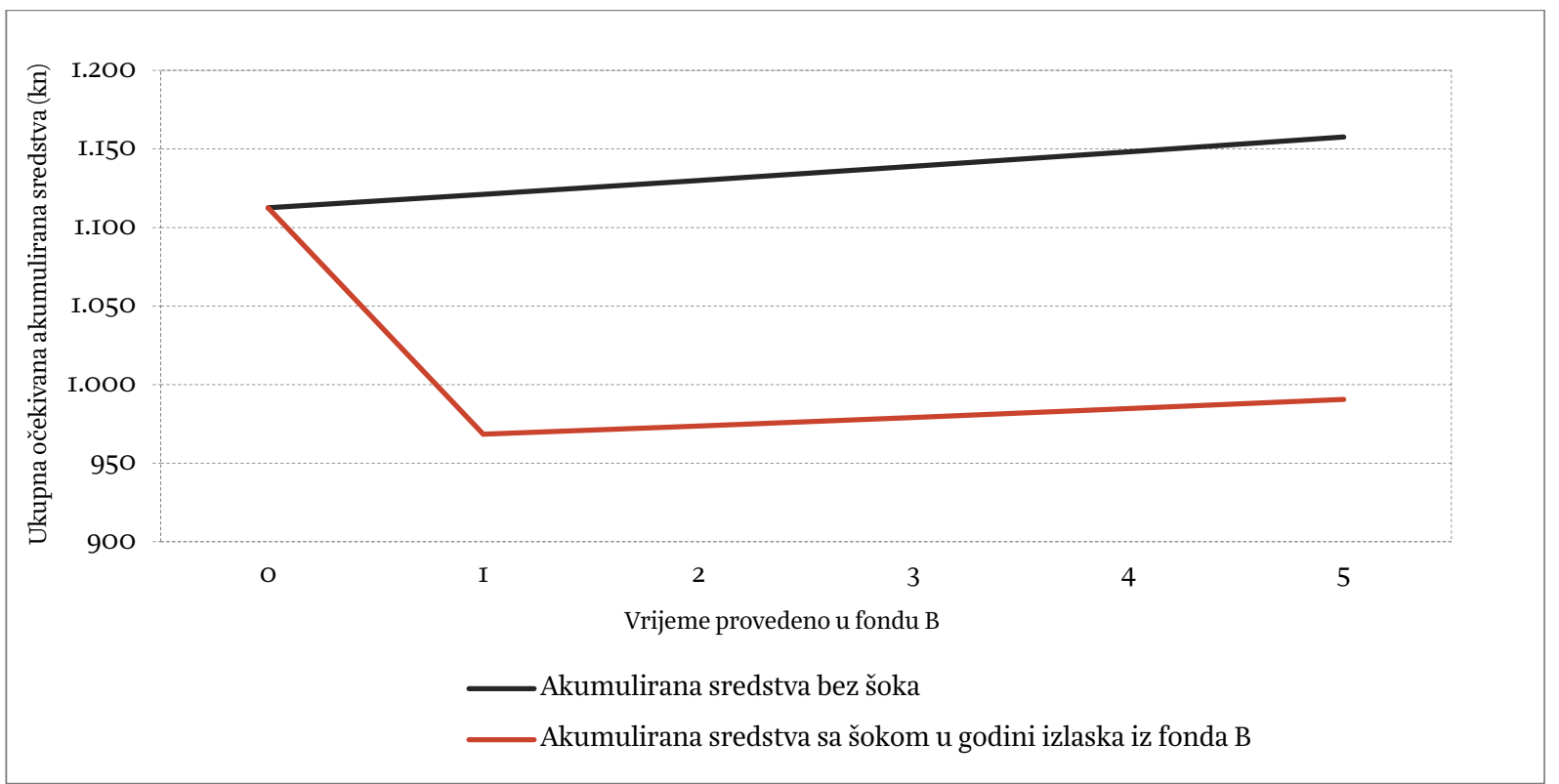

Kao što smo ranije spomenuli, nakon perioda štednje $\mathrm{u}$ fondu A, ukupna akumulirana sredstva prenesu se $\mathrm{u}$ fond B te se ukamaćuju po stopi prinosa fonda B. U ovom primjeru pretpostavljamo da se tržišni šok dogodio u trenutku kada je osiguranik član fonda B, tj. kada na osobnom računu ima već značajan iznos sredstava. Iz slike 2. vidljiv je značajan i nagli gubitak dotad akumuliranih sredstava. Također, vidljivo je i da razlika između akumuliranih sredstava bez šoka i sa šokom nakon kojeg član odluči promijeniti fond raste sa vremenom provedenim $\mathrm{u}$ fondu $\mathrm{B}$.

I6 Promotrimo situaciju kada se dogodi šok, no član ipak ne odluči promijeniti fond, već ostaje u fondu do očekivanih zakonskih ograničenja na trajanje članstva u pojedinom fondu (članak 93. Zakona o obveznim mirovinskim fondovima). Neka je $m$ trenutak kada se dogodi šok, a član odluči ostati $u$ fondu do automatskog prelaska u sljedeći fond. Ako se šok dogodi za vrijeme ulaganja u fond A, tada umjesto jednadžbe (6.3) imamo:

$$
M_{S, m}^{A}=R \cdot \frac{r_{A}-1}{r_{A}{ }^{1 / 12}-1} \cdot\left(\frac{r_{A}^{\left(m-t_{0}\right)}-s^{\left(m-t_{0}\right)}}{r_{A}-s} \cdot\left(1-S^{A}\right) \cdot r_{A}^{\left(t_{1}-m\right)}+s^{\left(m-t_{0}\right)} \cdot \frac{r_{A}^{\left(t_{1}-m\right)}-s^{\left(t_{1}-m\right)}}{r_{A}-s}\right) \cdot r_{B}^{\left(t_{2}-t_{1}\right)} \cdot r_{C}^{\left(T-t_{2}\right)},
$$

i tada ukupna očekivana akumulirana sredstva iznose:

$$
M_{P L C, m}^{S^{A}}=M_{S, m}^{A}+M^{B}+M^{C} .
$$

Ako se šok dogodi za vrijeme ulaganja $u$ fond $B$, tada umjesto jednadžbe (6.4) imamo

$$
M_{S, m}^{B}=R \cdot s^{t_{A}} \cdot \frac{r_{B}-1}{r_{B}{ }^{1 / 12}-1} \cdot\left(\frac{r_{B}^{\left(m-t_{1}\right)}-s^{\left(m-t_{1}\right)}}{r_{B}-s} \cdot\left(1-S^{B}\right) \cdot r_{B}^{\left(t_{2}-m\right)}+s^{\left(t_{2}-m\right)} \cdot \frac{r_{B}^{\left(t_{2}-m\right)}-s^{\left(t_{2}-m\right)}}{r_{B}-s}\right) \cdot r_{C}^{t_{C}},
$$

te tada ukupna očekivana akumulirana sredstva iznose:

$$
M_{P L C, m}^{S^{B}}=M^{A} \cdot\left(1-S^{B}\right)+M_{S, m}^{B}+M^{C} .
$$

Promotrimo situaciju kada se šok dogodi za vrijeme članstva u fondu A. Zanima nas kako će se to odraziti na očekivana ukupna akumulirana sredstva u slučaju da nakon šoka osiguranik ostane $u$ fondu A u odnosu na scenarij kada on nepovoljno odabere trenutak promjene fonda iz A u B. 
SLIKA 3.

Očekivana ukupna akumulirana sredstva (za jediničnu uplatu) u slučaju ostanka i odlaska nakon šoka u fondu A

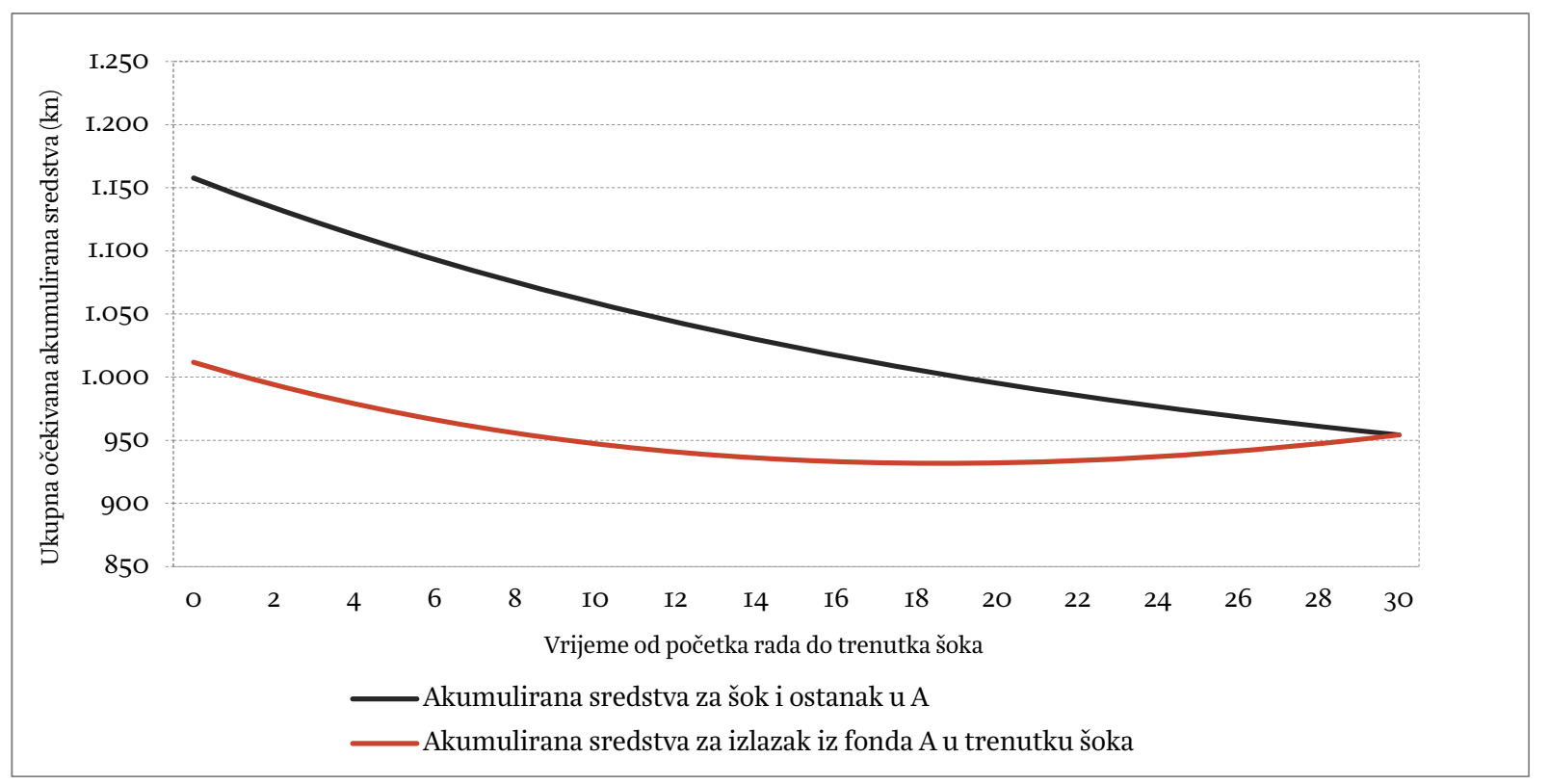

Vidljivo je da je za bilo koji trenutak šoka $m, t_{0} \leq m<t_{1}$, povoljnije ostati u fondu A nego prijeći u fond $\mathrm{B}$ u godini kada se šok dogodio. U trenutku šoka $m=t_{1}$ prelazak iz fonda A u B je obvezan, pa je iznos ukupnih očekivanih akumuliranih sredstava jednak za oba slučaja.

Promotrimo situaciju kada se šok dogodi za vrijeme članstva u fondu B. Zanima nas kako će se to odraziti na iznos ukupnih očekivanih akumuliranih sredstava u slučaju da nakon šoka osiguranik ostane $\mathrm{u}$ fondu B u odnosu na scenarij kada on nepovoljno odabere trenutak promjene fonda iz B u C.

\section{SLIKA 4.}

Očekivana ukupna akumulirana sredstva (za jediničnu uplatu) u slučaju ostanka i odlaska nakon šoka u fondu B

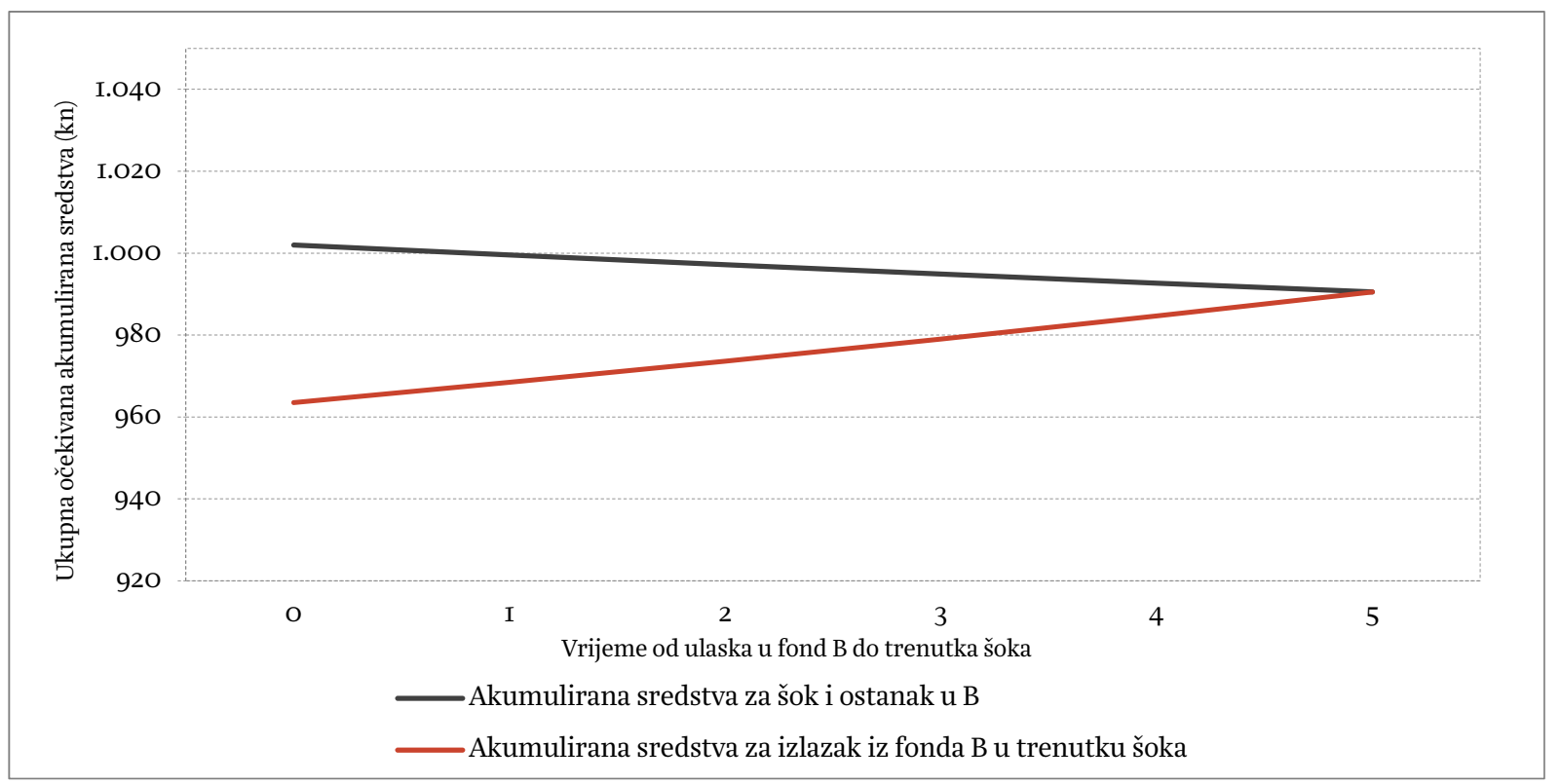


Vidljivo je da je za bilo koji trenutak šoka $m, t_{1} \leq m<t_{2}$, povoljnije ostati u fondu B nego prijeći u fond $\mathrm{C}$ u godini kada se šok dogodio. U trenutku šoka $m=t_{2}$ prelazak iz fonda $\mathrm{B}$ u $\mathrm{C}$ je obvezan, pa je iznos ukupnih očekivanih akumuliranih sredstava jednak za oba slučaja.

\section{ZAKLJUČAK}

Ovim je radom dan osvrt na novi model II. stupa mirovinskog osiguranja u Hrvatskoj koji po prvi puta uvodi zamjensko cjeloživotno modeliranje ulaganja za portfelje obveznih mirovinskih fondova, $u$ kojima osiguranici imaju priliku sami odabrati fondove različitog stupnja rizičnosti, uz određene uvjete na dob.

Obzirom na pretpostavke o očekivanim prinosima, rizicima i korelacijama između različitih klasa imovine te alokacijama portfelja mirovinskih fondova, izračunali smo očekivane realne prinose i rizike fondova kategorije A, B i C te smo dali usporedbu s rezultatima dobivenima temeljem strukture ulaganja prema dosadašnjem zakonu. Rezultati su u skladu s očekivanjima o boljoj izvedbi modela cjeloživotnog ulaganja spram ostalih modela u pogledu očekivanih prinosa i rizika.

Međutim, analiza pokazuje da očekivana rizičnost za fond $\mathrm{C}$ obzirom na fond B nije proporcionalno manja obzirom na smanjenje alokacije $u$ dionice. Razlog tome prvenstveno je nedovoljna diversifikacija ulaganja $u$ fondu kategorije C. U slučaju minimalnih promjena u alokaciji imovine fonda kategorije $\mathrm{C}$ u vidu mogućnosti postizanja male izloženosti prema dionicama te povećanju limita na izloženost inozemnim tržištima, očekivani realni prinosi fonda bi porasli, dok bi se očekivana rizičnost, zbog povećanja diversifikacije, smanjila. Obzirom da iznos smanjenja rizičnosti ovisi o procjenama nekoliko ključnih faktora, dobivene iznose smanjenja rizika treba shvatiti samo kao indikaciju nedostatka diverzifikacije za fond kategorije C.

U radu smo analizirali očekivana ukupna akumulirana sredstava za različite modele ulaganja te za jedan mogući dinamički cjeloživotni modela ulaganja. Osim očekivanih ukupnih akumuliranih sredstava, izračunali smo i vrijednost graničnog gubitka kojeg ne očekujemo premašiti u više od 2,5\% slučajeva, tj. iznos gubitka kojeg očekujemo da se ostvari jednom u 40 godina. Duljina članstva $u$ fondu kategorije A ovdje se pokazala kao najvažniji faktor $u$ određivanju očekivanih ukupnih akumuliranih sredstava, čak i u slučaju tržišnog šoka, tj. ostvarivanja graničnog gubitka. Pokazali smo da u slučaju ulaganja temeljenog na maksimalnom članstvu u fondovima kategorije A, B i C, uz zakonsko ograničenje članstva na pojedini fond (A-B-C shema), osiguranik bolje prolazi u zamjenskom cjeloživotnom modelu ulaganja nego u slučaju ulaganja po dosadašnjem zakonu, čak i u slučaju tržišnog šoka u trenutku umirovljenja.

Kako je pravilan odabir vremena prelaska iz mirovinskog fonda veće rizičnosti u fond manje rizičnosti bitan faktor kod određivanja očekivanog iznosa ukupnih akumuliranih sredstava $\mathrm{u}$ zamjenskom cjeloživotnom modelu ulaganja u II. stupu, pokazali smo efekt tržišnog šoka na očekivana ukupna akumulirana sredstva u slučajevima da se šok dogodio kada je osiguranik bio član fonda kategorije A, odnosno fonda kategorije B. Kao rezultat smo dobili da je za osiguranike povoljnije ne donijeti odluku o promijeni fonda, već ostati u fondu trenutačne kategorije sve do ograničenja trajanja članstva u tom fondu.

Dobiveni rezultati u ovom istraživanju pokazuju da su moguća daljnja poboljšanja II. stupa mirovinskog osiguranja u Hrvatskoj, posebno u završnoj fazi akumulacije sredstava $i$ to prije svega $u$ postavljanju investicijskih ograničenja za fondove kategorije C koja bi trebala rezultirati portfeljima 
obveznih mirovinskih fondova s boljim omjerom prinosa i rizika te daljnjom redukcijom VaR-a za iste. Također, potrebno je razmotriti uvjete za prelazak iz fonda veće rizičnosti $u$ fond manje rizičnosti $u$ proizvoljnom trenutku obzirom na utvrđeni rizik promjene fonda $u$ nepovoljnom trenutku, $t j$. prilikom pojave tržišnog šoka koji bi mogao osiguranike obeshrabriti spram ostanka u članstvu u fondu veće rizičnosti. U cilju daljnjeg istraživanja rizika promjene fondova različitih kategorija, nužno je istražiti i oportunost promjene fonda u suprotnom smjeru od ovdje analiziranog, a to je promjena fonda manje rizičnosti $u$ fond veće rizičnosti od strane osiguranika. Naime, ukoliko osiguranik na takav način promjeni fond te se u nekom trenutku dogodi tržišni šok, moguće je da do zakonskog uvjeta za ponovni prelazak $u$ fond niže rizičnosti neće biti dovoljno vremena za nadoknadu gubitaka $u$ odnosu na situaciju da član nije donio odluku o prelasku u fond veće rizičnosti. Analiza rizika upravo opisanog prelaska iz fonda manje rizičnosti u fond veće rizičnosti predstavlja logičan nastavak cjelokupne analize zamjenskog cjeloživotnog modela ulaganja mirovinskih fondova. Prethodno opisana analiza svih uočenih rizika u novom zamjenskom cjeloživotnom modelu ulaganja u II. stupu mirovinskog osiguranja u Hrvatskoj tek tada može poslužiti donositeljima zakonodavnog okvira za eventualne promjene u cilju daljnjeg poboljšanja mirovinskog sustava. 


\section{REFERENGE}

I. Arthur, G., 2009. Multifunds: Lessons from experience. Presentation on the International Conference on "Multifunds - Implementation and Prospects in the Pension System of the Central and Eastern European Countries”, Sofija, Bugarska.

2. Bagliano, F. C., Fugazza, C. i Nicodan, G., 2009. Life-Cycle Asset Allocation and Performance Evaluationon. Torino: Dipartimento di Scienze Economiche e Finanziarie "G. Prato" Università di Torino Torino : CeRP.

3. Bodie, Z., McLeavey, D. i Siegel, L. B., 2008. The Future of Life-Cycle Saving and Investing. Charlottesville: The Research Foundation of CFA Institute.

4. Castañeda, P. i Rudolph, H. P., 2OII. Upgrading Investment Regulations in Second Pillar Pension Systems - A proposal for Colombia. The World Bank, Policy Research Working Paper.

5. Dimson, E., March, P. R. i Staunton, M., 20I4. Credit Suisse Global Investment Returns Yearbook 20I4. Zurich: Credit Suisse Research Institute.

6. HANFA (Hrvatska agencija za nadzor financijskih usluga). Dostupno na: <www.hanfa.hr〉.

7. Impavido, G., Lasagabaster, E. i García-Huitrón, M., 20Io. New Policies for Mandatory Defined Contribution Pensions. Washington: The World Bank.

8. IOPS, 20I2. Supervising default investment funds. Working Papers on Effective Pensions Supervision, Br. I8. Dostupno na: 〈http://www.iopsweb.org/WpNor8Web.pdf〉.

9. Latković, M. i Liker, I., 2009. Sensitivity Analysis of the Pension System. Financial Theory and Practice, 33(4), str. 445-46I. Dostupno na: <http://fintp.hr/upload/files/ftp/2009/4/latkovicliker.pdf>.

IO. Potočnjak, Ž. i Vukorepa, I., 20I2. Modeling of life-cycle portfolios in capital-funded pension systems with defined contributions. Economic Trends and Economic Policy, (I3O), str. 29-59.

II. Scheuenstuhl, G. [et al.], 2OIO. Assessing Investment Strategies for Defined Contribution Pension Plans under various Payout Options. (A Background Paper to the OECD Policy Report).

I2. Shiller, R. J., 2006. Life-cycle personal accounts proposal for Social Security: An evaluation of President Bush's proposal. Journal of Policy Modeling, (28), str. 427-444. doi: IO.IOI6/j.jpolmod.2005.IO.0IO

I3. Šorić, K., 2000. The calculation of pensions based on individual capitalized savings. Accounting and Finance, (5), str. 75-87.

I4. UMFO, 20II. Pension reform in the Republic of Croatia - current effects, the current situation and recommendations for the future. Zagreb: The Association of Pension Funds and Pension Insurance.

I5. Viceira, L., 2009. Life cycle funds u: A. Lusardi, ur. Overcoming the saving slump: How to Increase the Effectiveness of Financial Education. University of Chicago Press and Saving Programs.

I6. Wojciech O., 20II. Redesigning fees and capital requirements For Polish Open Pension Funds. Dostupno na: <http://www.actuaries.org.uk/sites/all/files/documents/pdf/doI-redesigningfees-and-capital-requirements-polish-open-pension-funds.pdf .

17. Zakon o obveznim i dobrovoljnim mirovinskim fondovima, NN 49/99, 63/oo, IO3/O3, I77/O4, I4O/O5, 7I/O7, I24/IO, II4/II, 5IA/I3, I9/I4. Zagreb: Narodne novine. 